\title{
ARTICLES
}

\section{The Len Brown Affair The roles of new and old media in a New Zealand political sex scandal}

\begin{abstract}
The power of online media to influence New Zealand local government politics was made clear in 2013 when a blogger revealed that Len Brown, the popular mayor of Auckland, had conducted a two-year, extramarital affair. The mainstream media picked up the story, Brown's popularity collapsed and in late 2015 he announced he would not stand again for mayor. This media scandal was, in part, driven by the fact that Brown was a celebrity. Unlike several high-profile sex scandals involving politicians overseas, Brown's career did not survive the controversy, perhaps because the public came to regard him as a practised liar. The media itself engaged in self-serving scandalous activity during the controversy. Today's shock bloggers are similar to the proto-journalists of the 17 th century. Members of new and old media researching the scandal treated their secret sources very differently. The existence of the internet means such scandals can now exist in perpetuity. If the Len Brown Affair was an example of the media fulfilling its watchdog role_-by exposing a lying politician — it was also an example of journalists furthering their own ends - political and commercial-by appealing to their audiences' purient interests.
\end{abstract}

Keywords: celebrity, gossip, Len Brown, media scandals, new media, New Zealand, political journalism, politics, watchdog

\author{
GRANT HANNIS \\ Massey University, Wellington
}

\section{Introduction}

UCKLAND is New Zealand's largest city, with a population of about 1.4 million, a third of the country's total population (Statistics New Zealand, 2016). The city's recent political life has been dominated by a sex scandal involving its left-leaning mayor, Len Brown. A once-popular politican, the revelations of Brown's personal life, along with irregularities in his financial situation brought to light by the scandal, saw Brown's popularity plummet. Confronted with the inevitable loss he would suffer at the polls, Brown decided not to stand for re-election. 
Sex scandals involving politicians are nothing new, of course, but what was new about the Len Brown Affair was the part played by new media. The story was broken by Cameron Slater, an outspoken right-wing blogger. Slater had a political agenda in revealing the scandal - he wanted to destroy Brown's political career - and was able to use the relative freedom of the internet to do this. The mainstream media was forced to play catch-up, choosing to make known information that even Slater had decided not to reveal. For breaking such a major story, Slater was awarded the New Zealand journalism industry's inaugural best blog award. That accolade was controversial, particularly when emails hacked from Slater's account later revealed unsavoury details about how he researched the story.

This article considers the Len Brown Affair, in order to gain an understanding of the relative parts played by new and old media. My approach will be to first consider what scholars have concluded about overseas scandals. I will then recount the affair, clearly demarcating the roles played by new and old media. I will then discuss the insights gleaned and present my conclusions.

\section{Background}

A useful definition of media scandal is supplied by Lull and Hinerman (1997):

A media scandal occurs when private facts that disgrace or offend the idealized, dominant morality of a social community are made public and narrativized by the media, producing a range of effects from ideological and cultural retrenchment to disruption and change. (Lull \& Hinerman, 1997, p. 3)

That is to say, the media takes private information and makes it public, with the disclosure generally outraging society and producing any number of effects. The media's motives in doing this, the manner in which the outrage is reported and the precise effects engendered, have much occupied scholars.

Scandals often involve celebrities. It has been argued that the purpose of publishing scandals involving celebrities can be regarded as similar to that of dramatic tragedy: 'Effective gossip, like effective tragedy, delights in raising up its subjects on a pedestal and then delights in their fall back to ground' (Stephens, 2007, p. 95)

Perhaps the most well-known, political scandal was Watergate. In the early 1970s, The Washington Post helped break the story that then President Richard Nixon was involved in a cover-up to conceal the fact that the Republican Party had paid people to break into and bug the Democratic Party headquarters. Nixon was ultimately forced to resign (Woodward \& Bernstein, 2014).

The consequences of reporting a scandal may not always be as laudable as bringing down a corrupt leader. When a US college newspaper published the 
names of a pair of students caught having sex in a lift, the resulting embarrassment apparently saw the female student involved drop out of college (Knowlton $\&$ Reader, 2009). The newspaper's editor acknowledged that a major reason she published the piece was because her readers would find it interesting, but she also said it had a greater purpose: to warn others of the consequences of having sex in public. Knowlton and Reader (2009) were not convinced, saying this did not justify naming the couple. They also pointed out that such stories can remain on the internet for years, as the news media archives its stories online and others repost the items: 'The publication of such a story could very much impose a life sentence upon people who had long ago paid for their misdemeanor' (p. 141).

The audience's perceived moral stance can have a bearing on whether a news media outlet feels it should publish scandalous material. An audience that is 'generally tolerant of (or even demanding of) embarrassing information about individuals in their midst may give journalists a sense of licence to publish such information' (Knowlton \& Reader, 2009, p. 139). Reports on sexual misconduct, for instance, play a greater role in the content of the sensationalist and celebritygossip press because that is what its readers crave.

Sex scandals in the media have a long history. Publick occurrences both forreign and domestick, published in Boston in 1690 and often taken to be the first newspaper published in the American colonies, contained a scandalous report on sexual impropriety in the French royal family. The king's son, the newspaper related, 'has revolted against him [the king] lately, and has great reason, if reports be true, that the father used to lie with the son's wife' (Harris, 1690, p. 3). The author, Benjamin Harris, was rabidly anti-Catholic and no doubt took delight in making fun of the French royal family. Taking offence at such reportage-or perhaps just using it as a pretext to silence an independent media - the colonial government closed the paper down (Stephens, 2009).

In recent years, we can think of numerous sex scandals involving politicians. There was, for example, British politician Boris Johnson, who had extramarital affairs and fathered a love child (Morris, 2013); ex-US congressman Anthony Weiner, who engaged in extramarital sexting (FoxNews.com, 2013); US President Bill Clinton's affair with intern Monica Lewinsky (Morton, 2012); and the 2005 recordings that came to light recently of Donald Trump boasting about how he sexually harassed women (Fahrenthold, 2016). Politicians' careers can prove remarkably resilient to such scandal. Whereas Weiner eventually found himself unelectable, Johnson remains a high-profile politician and when Clinton left office most Americans thought he had done a good job despite his sexual controversies (Langer, 2001).

As for Trump, of course, he went on to be elected President.

We may be sceptical about the news media's motives in publishing sex scandals. The politican involved in such a scandal is typically caught telling lies 
and behaving immorally. In revealing such scandals it may be the case the media is fulfilling a watchdog role, helping to ensure our elected representatives are honest and morally upright. But it could simply be the media is catering to its audience's purient interest in the sleazier side of life to sell newspapers. Even in cases of genuine outrage, the breathless tone of much reporting of scandal renders it a media-constructed phenomenon: 'A muted police report and a redheadline media scandal...can report on exactly the same historical-factual event. Nevertheless, they are worlds apart from each other' (Ehrat, 2011, p. 7).

Even when media scandals result in regulatory or other significant change, it may not address the root cause of the problems. West (2006) points out that the financial scandals of WorldCom and Enron led to 'arguably the most thorough securities law revisions since the New Deal' (p. 325). But Bethany McLean, a journalist who played a key role in breaking the Enron scandal, was soon warning that the legal changes instituted had not stopped the attitudes that had created the scandals in the first place, citing the later subprime crisis as proof (McLean, 2008). Likewise, West notes that in Japan, an epidemic of men groping women in trains led to the introduction of women-only carriages. But police told him this meant women who continued to travel in mixed-sex carriages were regarded by gropers as 'asking for it' (West, 2006, p. 326). Nevertheless, West notes that scandals do act as a gauge of what is acceptable, 'forcing debate on topics that might otherwise have gone untouched, especially on taboo topics like sex' (p. 326).

Sometimes the media themselves are the perpetrator of scandalous activity. The News of the World's hacking of mobile phone records, including those of a murder victim, caused widespread outrage, ultimately leading to the paper's closure and the embarrassment of its press baron owner, Rupert Murdoch (Davies, 2014). Similarly, the scandal over CBS's reliance on bogus records about George Bush's military record - termed 'memogate' - tainted the reputation of leading journalist Dan Rather, who subsequently left the network (Ehrat, 2011). There is also the recent scandal of NBC news anchor Brian Williams falsely claiming to have been in an aircraft shot down during the Iraq War (Reuters, 2015).

So, we may have a clear idea of what a media scandal is and that they have always been popular with readers. But we are less clear on the media's motives in publishing scandals - is it to effect genuine change or just to profit from their audience's appetite for the outrageous? Also, it is not clear what effect publication can have. It may result in changes as profound and admirable as the removal of a corrupt president, but it may result simply in superficial regulatory change or be as unfortunate as a student deciding she must leave her studies due to personal embarrassment. In the modern digital age, such stories can exist indefinitely online. The woman at the centre of the Len Brown Affair found this out to her cost. 


\section{The Len Brown Affair}

\section{Background}

Len Brown originally trained as a lawyer, but began a successful local government political career in the greater Auckland region. He has been aligned to the New Zealand Labour Party since his youth. Manukau is the city immediately to the south of Auckland, and Brown was a Manukau City Councillor from the 1990s to the early 2000s (McCracken, 2010). Brown was elected Mayor of Manukau in 2007, winning comfortably (RNZ Newswire, 2007).

The New Zealand government then instituted a massive change in the structure of local government in the greater Auckland region, amalgamating several council organisations to create New Zealand's first 'super-city', Auckland (Orsman, 2008). Brown stood as mayor for this new entity in 2010. Despite a minor controversy, when it was revealed Brown had used his Manukau council credit card for about $\$ 800$ in personal expenses, he was elected Mayor of Auckland in a landslide (RNZ Newswire, 2010a; Mayor cuts up credit card, 2010; RNZ Newswire, 2010b). He was comfortably re-elected in 2013: Brown received about 150,000 votes; his nearest rival, right-wing candidate John Palino, received about 100,000 (RNZ Newswire, 2013). By then, Brown was in his mid-50s, married with teenage daughters. But at that point, the Len Brown Affair was revealed.

\section{New media breaks the story}

The story was broken by Cameron Slater, an outspoken, right-wing blogger, working with freelance journalist Stephen Cook. Slater, a portly man, had long been nicknamed 'The whale' and uses the expression as part of the name of his blog, 'Whale Oil' (www.whaleoil.co.nz). Slater is a shock blogger. His blog's writing style is brash and outrageous. Indeed, the full name of his blog, Whale Oil Beef Hooked, when said in an Irish accent, is a vulgar pun. Although an established blogger, Slater had a limited profile outside the relatively closed world of online political punditry. In breaking the Brown scandal, Slater exploded into the wider public consciousness.

Slater revealed on Whale Oil that Brown had recently conducted a two-year affair with a young woman. Slater did not name the woman, preferring to post on his website a sworn affidavit from her, with many identifying details - including her name - redacted (Slater, 2013a). The affidavit featured graphic descriptions of the sexual aspects of the relationship, which included Brown and his mistress having sex on council premises.

In his blog, Slater gave several reasons as to why he had revealed the affair, including that as mayor of New Zealand's largest city, Brown had paraded his family for the cameras, including on election night, and had used council premises

for the affair (Slater, 2013b). Slater repeatedly called on Brown to resign, calling him 'Lusty Len', a 'creepy, sneaky, little ratbag', 'the rooting ratbag mayor' and 'a 
duplicitous liar' (Slater, 2013c, para. 1; Slater, 2014, para. 3, Slater, 2013b, para. 7).

\section{Old media provides balance and deepens the scandal}

The story became national news and Brown faced a publicity maelstrom. Brown quickly went on a public relations offensive and used the mainstream media to do so. On national television, he admitted the affair and apologised for it, declaring: 'I have caused my wife and my children harm and shame and humiliation', but asking the people of Auckland to 'stand by me', as he intended to continue to be their mayor (Campbell Live, 2013, paras. 4 and 10).

However, although the mainstream media gave Brown the opportunity to put his case, it also escalated the scandal. While the name of Brown's mistress was obscured in the affidavit Slater published, there was sufficient information in the document to make identifying her relatively easy. Her name, Bevan Chuang, was quickly revealed by the main newspaper in Auckland, The New Zealand Herald (Savage, 2013a). Very quickly all media, including Whale Oil, were using her name, interviewing her and reporting comments she posted online.

The mainstream media also revealed more about Slater. He acknowledged he had a political motivation to reveal the affair: 'Of course politics was involved. Of course I wanted to knock Len Brown over' (Slater, quoted in Day, 2013, para. 31).

The media also reported that Chuang had been in a relationship with Luigi Wewege, a member of Palino's mayoral campaign team. Wewege denied this, saying he and Chuang were merely friends, but Chuang produced Facebook messages between her and Wewege in which he said he loved her and could not wait to lie in bed with her (Espiner, 2013). Wewege and Slater also knew each other, and had been Facebook friends since 2012 (Hager, 2014, p. 109).

The Herald began to reveal unflattering details about Chuang. The newspaper reported that during the time she was having an affair with Brown she had applied for a job at a council-run organisation, for which Brown had given her a reference. She secured the job, but later left it, and was convicted for unlawfully accessing her former employer's computer system (Savage, 2013b; Savage, 2013c).

Such revelations led the council to commission an independent report on Brown (Mason, 2013; EY, 2013). It found Brown had made 1400 calls and texts on his council phone to Chuang over the past previous years. Combing over his financial records to see if he had used council funds to conduct his affair, the report instead found Brown had failed to declare his and his family's use of free hotel rooms and upgrades in the city, worth nearly $\$ 40,000$. In the wake of this, the Herald joined Slater in calling on Brown to resign (Editorial: Brown must go, 2013). With supporters abandoning him in droves, Brown did not run for mayor in the 2016 election.

The mainstream New Zealand journalism industry's awards are the Canon Media Awards. In 2014, Slater won the inaugural Canon award for best blog 
because of the Len Brown story (Canon Media Awards, 2016). The win was controversial. At least one Herald journalist heckled Slater as he collected his award. Herald editor Tim Murphy reportedly apologised to Slater for this (Glucina, 2014a; Glucina, 2014b).

\section{An investigative journalist steps in}

Three months after Slater received his Canon award, the controversy was dramatically re-ignited when investigative journalist Nicky Hager published a book based on thousands of Slater's emails that an unidentified third party had hacked from Slater's computer and leaked to Hager (Hager, 2014). The book covered a wide variety of topics - including Slater's close links with the National-led government and his relationship with public relations people and lobbyists - but included a chapter on the scandal. Hager showed how Wewege had long pressured Chuang into going public and that Slater had hoped Brown would be forced to resign and Palino become mayor. Hager also revealed that after the scandal broke Slater had unsuccesfully tried to find evidence Brown used prostitutes (Hager, 2014).

Hager revealed that Slater and Cook had a dismissive attitude towards their source. In an online exchange between the two, Cook referred to her as 'Fucken Chung', misspelling her name, and Slater called her a 'Stupid tart' (Hager, 2014, p. 116). As well as sneering at Chuang, Slater also held the mainstream media in contempt. Hager quoted Slater as saying: 'I am friends with a great many media people ... how do you think they get their stories[?]' and 'Do these media c**ts ever get any ideas from their own brains?' (Slater, quoted in Hager, pp. 117, 118).

Hager concluded that Slater's actions should have 'totally discredited him' (p. 117). Activities such as pressuring a source to go public and being driven by political motivations 'would be the end of a journalist's reputation' (p. 117). Hager said Slater's winning of a Canon Media Award was 'a sad joke' (p. 117).

Hager argued that the public's right to know about Slater's activities justified the breach of his privacy. Hager launched the book in a blaze of publicity just before a general election, which saw a National-led government re-elected. Slater was enraged, hurling expletive-laden abuse at Hager and saying Hager 'is a purveyor of stolen documents and he makes money fencing those documents' (Slater, 2016, para. 12). Whale Oil claimed Hager had launched the book in a failed attempt to influence the outcome of a general election (Whale Oil Staff, 2015).

In light of Hager's revelations, there were calls on social media for Slater's Canon award be withdrawn (Neville, 2014), but the Newspaper Publishers Association, which runs the Canon Media Awards, was not swayed. The association's head said: 'This particular award was made by independent judge Deborah Hill Cone in recognition of Whale Oil having broken a major story relating to the 
Mayor of Auckland, Len Brown. This story was followed up by mainstream media including newspapers, television and radio for many weeks' (Neville, para. 6).

Following a complaint from Slater, the police have sought to uncover the identity of the hacker who provided Hager with his information, so far without success (Morrison, 2015; Hager: Police raid, 2015).

\section{Discussion and conclusions}

We can draw several firm conclusions by applying the insights from the overseas literature to the narrative account of the Len Brown Affair.

The Len Brown Affair was a media scandal. Following Lull and Hinerman (1997), the Affair had all the hallmarks of a media scandal. There was the publication of private details that offended the dominant morality in society - that is to say, the affair between Brown and Chuang. The scandal was narrativised by the media, both new (Whale Oil) and old (the Herald, Campbell Live) and Nicky Hager. The scandal also produced disruption and change. Brown's popularity plummeted and he had no option but to abandon his plan to seek re-election.

Brown's celebrity helped fuel the scandal. As Stephens (2007) noted, celebrity scandals are akin to dramatic tragedies, with the well-known tripped up by their all-too-human weaknesses. If Brown had been an unknown, his affair would not have been deemed newsworthy.

The public does not always forgive. While many overseas politicians' careers have survived sex scandals (Morris, 2013; Morton, 2012; Fahrenthold, 2016; Langer, 2001), Brown's did not. This was likely due to a combination of factors. Some Auckland voters would have simply found the affair morally unacceptable because Brown had broken his marriage vows. Worse, the affair lasted for two years. This indicated Brown had for a long time lied to many people - family, friends and colleagues — in order to conduct the affair. Further, he conducted the affair on council premises, showing he did not treat his position as mayor with appropriate respect. There was also the fact the affair revealed irregularities in how Brown used council funds, a seemingly persistent problem in that Brown had been forced to repay money after behaving similarly when Mayor of Manukau. Taken together, these factors likely suggested to Auckland's voters that Brown was morally bankrupt and untrustworthy.

The media engaged in its own self-serving scandalous activity. The media themselves can be perpetrators of scandalous activity, in part because this can be what their audiences crave (Davies, 2014; Ehrat, 2011; Knowlton \& Reader, 2009).

Consider Slater. Whale Oil is written in a graphic, outrageous style and is rabidly anti-left. That is what the blog's audience clearly wants. Slater knew his readers would relish reading about the left-leaning Brown's sexual impropriety, especially the affidavit's salacious details. The details would have been personally 
embarassing to Brown. Slater thus gave his audience what it wanted. Chuang's affidavit could not be printed in the mainstream media, or a link provided to it on a mainstream media website. It was simply too explicit, too scandalous.

Likewise, consider the Herald. Scooped by Whale Oil, the Herald did what Slater chose not to do, identify Chuang by name, in order to regain the competitive initiative. The newspaper also revealed her criminal record. If the Herald had not done so, it is likely some competing mainstream media outlet would have. In light of this, it was surely hypocritical for a Herald journalist to heckle Slater at the Canon awards.

Even the morality of Hager, who did much to reveal Slater's actions, might be questioned. After all, his book is based on emails a third party stole from Slater and gave to Hager. Hager argued that the public interest in revealing this information justified breaching Slater's privacy. That may be the case. Slater, not surprisingly, did not agree.

The shock blogger is akin to the scandalous proto-journalist of early newspaper history. Slater saw the sex scandal as a way of driving Brown from office. For Slater, revealing the scandal was a means to an end-to pursue his political agenda. In one sense, this is nothing new. In the early days of the American press, another period of anarchic single-person media outlets, the anti-Catholic Benjamin Harris did the same thing with his revelations about the French royal family. We could say shock bloggers have brought that part of journalism history full circle.

Sources must chose their journalists carefully. Slater and his associates applied considerable pressure on their source, Bevan Chuang, to go public. Far more so, I suggest, than the mainstream media would have countenanced. Moreover, Slater regarded his source with disdain and, either through incompetence or indifference, published so much about his supposedly secret source that she was quickly identified. The mainstream media would treat a secret source with far greater care and consideration. Indeed, one marked difference between Slater and Hager, is how they treated their anonymous sources. Slater allowed his to be identified almost immediately. Hager has carefully protected his and says he would go to prison rather than reveal his source (Heather \& Shadwell, 2014).

The internet makes scandals permanent. In the digital realm, it is effectively impossible to have your transgressions forgotten (Knowlton \& Reader, 2009). While hard-copy newspaper articles could soon be forgotten and their archives difficult to store and search, anyone can now type a name into a search engine to discover someone's past. The details of Chuang's two-year affair with Brown will likely be easily accessible on the internet indefinitely, including her affidavit. This is despite the fact she originally thought her identity would remain secret. Brown will likely have the details of his moral shortcomings, including the EY (2013) independent report into his affair, available for all to see in perpetuity. 
So what, finally, can we say about media scandals? Are they part of the media's watchdog role to keep the powerful honest? Or are they simply a way journalists can generate, maintain and influence an audience, by appealing to their audiences' prurient interests? The Len Brown Affair reveals that media scandals can be both.

\section{References}

Campbell Live. (2013, October 15). My apologies but stand by me. Retrieved from www.3news.co.nz/tvshows/campbelllive/my-apologies-but-stand-by-me--len-brown2013101519\#axzz3S3UuXnmu

Canon Media Awards. (2016). Previous winners 2014. Retrieved from www.canonmediaawards.co.nz/previous-winners

Davies, N. (2014). Hack attack: The inside story of how the truth caught up with Rupert Murdoch. New York, NY: Faber and Faber.

Day, S. (2013, October 17). Brown helped Chuang get a job. Retrieved from www.stuff. co.nz/national/politics/9292175/Brown-helped-Chuang-get-a-job

Editorial: Brown must go for the good of the Super City (2013, December 18). Retrieved from www.nzherald.co.nz/super-city/news/article.cfm?c id=1501110\&objectid $=11174068$

Ehrat, J. (2011). Power of scandal. Toronto, Canada: University of Toronto Press.

Espiner, C. (2013, October 17). New claims may save Brown. Retrieved from www.stuff. co.nz/national/politics/opinion/9295009/New-claims-may-save-Brown

EY. (2013). Independent review commissioned by the Auckland Council chief executive. Retrieved from www.aucklandcouncil.govt.nz/SiteCollectionDocuments/Independent\%20Review\%20Report\%20FINAL\%20131213.pdf

Fahrenthold, D. (2016, October 8). Trump recorded having extremely lewd conversation about women in 2005. Retrieved from www.washingtonpost.com/ politics/trump-recorded-having-extremely-lewd-conversation-about-women-in2005/2016/10/07/3b9ce776-8cb4-11e6-bf8a-3d26847eeed4_story.html

FoxNews.com. (2013, September 11). Sydney Leathers crashes sexting partner Anthony Weiner's concession party. Retrieved from www.foxnews.com/entertainment/2013/09/11/sydney-leathers-crashes-sexting-partner-anthony-weiner-concession-party.html

Glucina, R. (2014a, May 9). Well done to WhaleOil [Twitter post]. Retrieved from twitter.com

Glucina, R. (2014b, May 9). Award winning. [Twitter post]. Retrieved from twitter.com Hager: Police raid 'weird overkill' (2015, December 18). Retrieved from www.newshub.co.nz/nznews/hager-police-raid-weird-overkill-2015121808\#axzz4CHBGr5d9

Hager, N. (2014). Dirty politics: How attack politics is poisoning New Zealand's political environment. Nelson, NZ: Craig Potton Publishing.

Harris, B. (1690). Publick occurrences both forreign and domestick. Boston, MS: R. Pierce.

Heather, B. \& Shadwell, T. (2014, October 7). Hager vows to protect hacker's ID. www. stuff.co.nz/national/politics/10585923/Hager-vows-to-protect-hackers-ID

Knowlton, S. \& Reader, B. (2009). Moral reasoning for journalists. Westport, CT: Praegar.

Langer, G. (2001, January 17). Poll: Clinton legacy mixed. Retrieved from http://abcnews. go.com/Politics/story?id=120952 
Lull, J. \& Hinerman, S. (eds.) (1997). Media scandals: Morality and desire in the popular culture marketplace. Cambridge, UK: Polity.

Mason, C. (2013, December 13). Len Brown's calls, texts and hotel stays revealed. Retrieved from www.nzherald.co.nz/nz/news/article.cfm?c_id=1\&objectid=11172021

Mayor cuts up credit card. (2010, June 9). Waikato Times. p. 2.

McCracken, H. (2010, June 6). 'Grey man' to lead the supercity? Retrieved from www. nzherald.co.nz/auckland-region/news/article.cfm?1 id=117\&objectid=10649966

McLean, B. (2008). The smartest guys in the room: Covering the Enron saga, Pacific Journalism Review 1 (14), pp. 15-31. Retrieved from https://pjreview.aut.ac.nz/sites/ default/files/articles/pdfs/PJR\%2014\%281\%29\%20EronSaga\%20pp15-31.pdf

Morris. N. (2013, May 30). He's fathered a love child and had three affairs, but the British public still loves Boris Johnson. Retrieved from www.independent.co.uk/news/uk/ politics/he-s-fathered-a-love-child-and-had-three-affairs-but-the-british-public-stillloves-boris-johnson-8636709.html

Morrison, A. (2015, July 15). Judge reserves decision on police raid on Hager's home. Retrieved from www.tvnz.co.nz/one-news/new-zealand/judge-reserves-decision-onpolice-raid-hager-s-home-q01682

Morton, A. (2012). Monica's story. London, UK: Michael O’Mara Books.

Neville, R. (2014, August 15). Newspaper publishers rebuff attacks on Canon. Retrieved from www.canonmediaawards.co.nz/announcements/newspaper-publishers-rebuffattacks-on-canon

Orsman, B. (2008, June 25). Super city's council Australasia's biggest. Retrieved from www.nzherald.co.nz/nz/news/article.cfm?c_id=1\&objectid=10518213

Reuters. (2015, Febraury 10). NBC news anchor Brian Williams suspended after Iraq misstatement. Retrieved from www.cnbc.com/id/102415083\#.

RNZ Newswire. (2007, October 13). Vote-Len. [Radio broadcast]. Retrieved from $w w w$. nznewswire.co.nz

RNZ Newswire. (2010a, June 16 2010). Emotional mayor regrets use of council credit card. Retrieved from www.radionz.co.nz/news/regional/54042/emotional-mayorregrets-use-of-council-credit-card

RNZ Newswire. (2010b, October 9). Brown elected Auckland's first super city mayor. Retrieved from www.radionz.co.nz/news/local-elections-2010/59029/brown-electedauckland's-first-super-city-mayor

RNZ Newswire. (2013, October 12). Len Brown wins second term as Auckland mayor. [Radio broadcast]. Retrieved from www.nznewswire.co.nz

Savage, J. (2013a, October 15). Mayor Len Brown, the other woman. Retrieved from www.nzherald.co.nz/nz/news/article.cfm?c id=1\&objectid=11140517

Savage, J. (2013b, October 17). Revealed: Chuang's computer criminal past. Retrieved from www.nzherald.co.nz/nz/news/article.cfm?c_id=1\&objectid=11141538

Savage, J. (2013c, October 17). Mayor provided reference for job at council-run art gallery. Retrieved from www.nzherald.co.nz/nz/news/article.cfm?c id=1\&objectid=11141316

Slater, C. (2013a, October 15). Exclusive - the affidavit. Retrieved from www.whaleoil. co.nz/2013/10/exclusive-affidavit/

Slater, C. (2013b, October 15). Why we broke the story of the rooting ratbag mayor. Retrieved from www.whaleoil.co.nz/2013/10/broke-story/

Slater, C. (2013c, October 20). Lusty Len goes international. Retrieved from www. whaleoil.co.nz/2013/10/lusty-len-goes-international/

Slater, C. (2014, March 16). Wrong again Len, just go already. Retrieved from www. whaleoil.co.nz/2014/03/wrong-len-just-go-already/ 
Slater, C. (2016). Hooton on Hager's humungous hypocrisy. Retrieved from www. whaleoil.co.nz/2016/05/hooton-hagers-humungous-hypocrisy/

Statistics New Zealand. (2016). Auckland. Retrieved from www.stats.govt.nz/ Census/2013-census/profile-and-summary-reports/quickstats-about-a-place. aspx?request_value $=13170 \&$ tabname $=$

Stephens, M. (2007). A history of news, New York, NY: Oxford University Press.

West, M. (2006). Secrets, sex, and spectacle. Chicago, IL: University of Chicago Press.

Whale Oil Staff. (2015, December 19). Open letter to Nicky Hager. Retrieved from www. whaleoil.co.nz/2015/12/open-letter-to-nicky-hager/

Woodward, B. \& Bernstein, C. (2014). All the president's men. New York, NY: Simon and Schuster.

Dr Grant Hannis is associate professor of journalism at Massey University in Wellington, New Zealand. His research interests include journalism history and the teaching of journalism.

g.d.hannis@massey.ac.nz

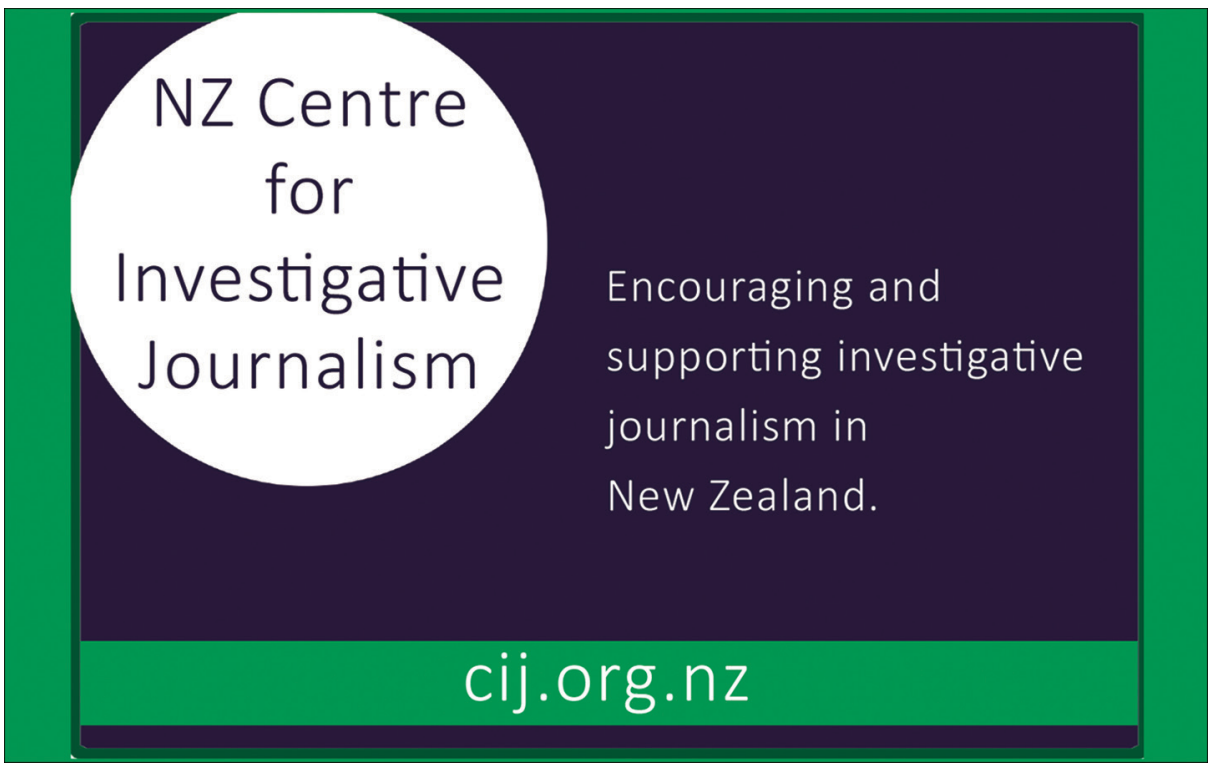

